University of Nebraska - Lincoln

DigitalCommons@University of Nebraska - Lincoln

2012

\title{
Oxygenation properties and oxidation rates of mouse hemoglobins that differ in reactive cysteine content
}

Jay F. Storz

University of Nebraska-Lincoln, jstorz2@unl.edu

Roy E. Weber

Aarhus University, Denmark, roy.weber@biology.au.dk

Angela Fago

Aarhus University, Denmark, angela.fago@biology.au.dk

Follow this and additional works at: https://digitalcommons.unl.edu/bioscistorz

Part of the Genetics and Genomics Commons

Storz, Jay F.; Weber, Roy E.; and Fago, Angela, "Oxygenation properties and oxidation rates of mouse hemoglobins that differ in reactive cysteine content" (2012). Jay F. Storz Publications. 51.

https://digitalcommons.unl.edu/bioscistorz/51

This Article is brought to you for free and open access by the Papers in the Biological Sciences at DigitalCommons@University of Nebraska - Lincoln. It has been accepted for inclusion in Jay F. Storz Publications by an authorized administrator of DigitalCommons@University of Nebraska - Lincoln. 


\title{
Oxygenation properties and oxidation rates of mouse hemoglobins that differ in reactive cysteine content
}

\author{
Jay F. Storz, ${ }^{1}$ Roy E. Weber, ${ }^{2}$ and Angela Fago ${ }^{2}$ \\ 1. School of Biological Sciences, University of Nebraska, Lincoln, NE 68588, USA \\ 2. Zoophysiology, Department of Biological Sciences, Aarhus University, DK-8ooo, Aarhus C, Denmark \\ Corresponding author - J. Storz, tel 402 472-1114, fax 402 472-2083, email jstorz2@unl.edu
}

\begin{abstract}
House mice (genus Mus) harbor extensive allelic variation at two tandemly duplicated genes that encode the $\beta$-chain subunits of adult hemoglobin $(\mathrm{Hb})$. Alternative haplotypes differ in the level of sequence divergence between the two $\beta$-globin gene duplicates: the $H b b^{d}$ and $H b b^{p}$ haplotypes harbor two structurally distinct $\beta$-globin genes, whereas the $H b b^{s}$ haplotype harbors two $\beta$-globin duplicates that are identical in sequence. One especially salient difference between the $s$-type Hbs relative to the $d$-and $p$-type Hbs relates to the number of reactive $\beta$-chain cysteine residues. In addition to the highly conserved cysteine residue at $\beta 93$, the $d$-and $p$-type Hbs contain an additional reactive cysteine residue at $\beta_{13}$. To assess the functional consequences of allelic variation in $\beta$-globin cysteine content, we measured $\mathrm{O}_{2}$-binding properties and $\mathrm{H}_{2} \mathrm{O}_{2}$-induced oxidation rates of mono- and dicysteinyl $\beta$-Hbs from 4 different inbred strains of mice: $\mathrm{C}_{57} \mathrm{BL} / 6 \mathrm{~J}$, BALB/CJ, MSM/Ms, and CAROLI/EiJ. The experiments revealed that purified Hbs from the various mouse strains did not exhibit substantial variation in $\mathrm{O}_{2}$-binding properties, but $s$-type $\mathrm{Hb}$ (which contains a single reactive $\beta$-chain cysteine residue) was far more readily oxidized to $\mathrm{Fe}^{3+}$ metHb by $\mathrm{H}_{2} \mathrm{O}_{2}$ than other mouse Hbs that contain two reactive $\beta$-chain cysteine residues. These results suggest that the possession of an additional reactive cysteine residue may protect against metHb formation under oxidizing conditions. The allelic differences in $\beta$-globin cysteine content could affect aspects of redox signaling and oxidative/ nitrosative stress responses that are mediated by $\mathrm{Hb}$-S-nitrosylation and Hb-S-glutathionylation pathways.
\end{abstract}

Keywords: globins, hemoglobin, met-hemoglobin, Mus, oxidative stress

\section{Introduction}

Electrophoretic surveys of wild house mice (genus Mus) have revealed striking patterns of allelic polymorphism at two tandemly duplicated genes that encode the $\beta$-chain subunits of adult hemoglobin (Hb) (Selander and Yang, 1969; Selander et al., 1969a, b; Miyashita et al., 1985; Kawashima et al., 1995). In natural populations of Eurasian house mice, three main classes of $\beta$-globin haplotype have been characterized: $H b b^{d}, H b b^{p}$, and $H b b^{s}$ (Erhart et al., 1985; Storz et al., 2007; Runck et al., 2009, 2010). These alternative haplotypes differ in the level of sequence divergence between the two $\beta$-globin gene duplicates, $H B B$ - $T_{1}$ and $H B B-T 2$. The $H b b^{d}$ and $H b b^{p}$ haplotypes harbor two structurally distinct $\beta$-globin genes, and in each case, the more highly expressed $H B B-T_{1}$ gene encodes the $\beta$-chain subunits of the major $\mathrm{Hb}$ isoform (isoHb) whereas $H B B-T_{2}$ encodes the $\beta$ - chains of the minor isoHb (Whitney, 1977; Leder et al., 1980). In contrast to the two distinct $\beta$-globin duplicates on the $H b b^{d}$ and $H b b^{p}$ haplotypes, the $H b b^{s}$ haplotype harbors two $\beta$-globin duplicates that are identical in sequence (Erhart et al., 1985; Storz et al., 2007; Hoffmann et al., 2008). Thus, mice that are homozygous for the $H b b^{s}$ haplotype synthesize a single $\beta$-chain isoHb during postnatal life.
One especially noteworthy difference between the $s$-type Hbs relative to the $d$ - and $p$-type Hbs relates to the number of reactive $\beta$-chain cysteine residues. All of the mouse Hbs contain the highly conserved cysteine at $\beta 93\left(\mathrm{~F}_{9}\right)$, which is present in the $\beta$-globins of all mammals and birds examined to date (Riggs, 1960; Reischl et al., 2007; Jensen, 2009), but the $d$ - and $p$-type Hbs contain an additional reactive cysteine residue at $\beta_{13}$ (A10). The sulfhydryl $-\mathrm{SH}$ group of $\beta 93 \mathrm{Cys}$ plays an important role in the formation of mixed disulfides with low molecular mass thiols like glutathione (Murakami and Mawatari, 2003; Thomas et al., 2003; Giustarini et al., 2006; Hempe et al., 2007; Colombo et al., 2010) and the role of $\beta 93$ S-nitrosylation in transducing hypoxic nitric oxide (NO) vasoactivity is a matter of ongoing debate (reviewed by Gladwin and Kim- Shapiro, 2008; Jensen, 2009; Reeder, 2010). Studies of mouse Hbs by Hempe et al. (2007) demonstrated that both $\beta_{13}$ Cys and $\beta_{93}$ Cys form mixed disulfides with glutathione under oxidizing conditions and that $\beta_{13} C y s$ is especially reactive. Thus, mice that express the $d$ - and $p$-type Hbs have red cells with an elevated concentration of reactive sulfydryl groups relative to mice that only express $s$-type $\mathrm{Hbs}$, and this results in pronounced differences in the blood-mediated metabolism of oxidants and thiol reactants such as $\mathrm{NO}$ and glutathione (Miranda, 2000; Giustarini et al., 2006; Hempe et al., 2007). 
Results of previous studies indicated that the various $\mathrm{Hb}$ types of house mice exhibit slight differences in $\mathrm{O}_{2}$ affinity (Newton and Peters, 1983; Uchida et al., 1998; Runck et al., 2010). However, much more dramatic functional differences between monocysteinyl ( $s$-type) $\beta$-Hbs and dicysteinyl ( $d$ - and $p$-type) $\beta$-Hbs are manifest under conditions of oxidative stress. Specifically, red cells of mice expressing dicysteinyl $\beta$-Hbs are far more susceptible to oxidantinduced hemolysis than are those of mice expressing monocysteinyl $\beta$-Hbs (Kruckeberg et al., 1987). Studies by Kruckeberg et al. (1987) demonstrated that susceptibility to red cell hemolysis was positively associated with the rate of membrane lipid oxidation, as measured by the formation of malonyldialdehyde, a fatty acid oxidative breakdown product. Red cells that were susceptible to oxidant-induced hemolysis showed a rapid rate of malonyldialdehyde formation, whereas red cells that were resistant to hemolysis showed a far lower rate of malonyldialdehyde formation. These results suggest that differences in $\beta$-globin cysteine content may be responsible for differences in heme oxidation rates, which in turn influences cell survival under oxidative stress. This is because Hbs in the ferrous $\mathrm{Hb}-\mathrm{Fe}^{2+}$ or ferric $\mathrm{Hb}-\mathrm{Fe}^{3+}$ (metHb) states react with hydrogen peroxide $\left(\mathrm{H}_{2} \mathrm{O}_{2}\right)$ and/ or lipid hydroperoxides to form a ferryl $\mathrm{Fe}^{4+}$ heme and a proteincentered radical in the reaction with metHb (Alayash et al., 2001).

Such products can promote lipid oxidation (Harel and Kanner, 1986; Everse and Hsia, 1997; Umbreit, 2007), a process that may be further enhanced by the release of hemin from metHb subunits (Everse and Hsia, 1997; Reeder, 2010). However, experimental studies of human red cells have revealed a complex association between rates of $\mathrm{Hb}$ oxidation and the susceptibility to oxidant-induced hemolysis (Trotta et al., 1981, 1982, 1983). Paradoxically, red cells that accumulated a higher concentration of metHb experienced lower levels of membrane lipid oxidation. Under conditions of oxidative stress, metHb appears to protect against oxidative damage to the red cell membrane by scavenging reactive intermediates that propagate lipid peroxidation chain reactions. The oxidation of $\beta 93$ Cys to cysteic acid has been proposed to play a role in the scavenging of free radicals generated by reactions of ferrous and ferric heme with $\mathrm{H}_{2} \mathrm{O}_{2}$, thereby protecting other cellular components from oxidative damage (Jia et al., 2007; Reeder, 2010; Widmer et al., 2010).

To assess the functional consequences of allelic variation in $\beta$-globin cysteine content, we measured $\mathrm{O}_{2}$-binding properties and $\mathrm{H}_{2} \mathrm{O}_{2}$-induced oxidation rates of mono- and dicysteinyl $\beta$-Hbs from 4 different inbred strains of mice: $C_{57} \mathrm{BL} / 6 \mathrm{~J}$, $\mathrm{BALB} / \mathrm{cJ}, \mathrm{MSM} / \mathrm{Ms}$, and CAROLI/EiJ. The experiments revealed that purified Hbs from the various mouse strains did not exhibit substantial variation in $\mathrm{O}_{2}$-binding properties, but $s$-type $\mathrm{Hb}$ (which contains a single reactive $\beta$-chain cysteine residue) was far more readily oxidized to $\mathrm{Fe}^{3+}$ by $\mathrm{H}_{2} \mathrm{O}_{2}$ than other mouse $\mathrm{Hbs}$ that contain two reactive $\beta$-chain cysteine residues. These results suggest that the possession of an additional reactive cysteine residue may protect against metHb formation under oxidizing conditions. If so, then these allelic differences in $\mathrm{Hb}$ oxidation rates may underlie previously documented variation in S-nitrosylation, S-glutathionylation, and the susceptibility to red cell hemolysis under oxidative stress (Kruckeberg et al., 1987; Giustarini et al., 2006; Hempe et al., 2007).

\section{Materials and methods}

\subsection{Samples}

We measured $\mathrm{O}_{2}$-binding properties and oxidation rates of purified hemolysates from 4 different inbred strains of mice: $\mathrm{C}_{57} \mathrm{BL} / 6 \mathrm{~J}, \mathrm{BALB} / \mathrm{cJ}, \mathrm{MSM} / \mathrm{Ms}$, and CAROLI/EiJ. The $\mathrm{C}_{57} \mathrm{BL} / 6 \mathrm{~J}$ and BALB/CJ strains are referable to Mus musculus domesticus, the MSM/Ms strain is referable to M. musculus molossinus, and the CAROLI/EiJ strain is referable to $M$. caroli. Blood samples from each of the 4 strains were obtained from the Jackson Lab (Bar Harbor, ME, USA). Blood samples from the MSM/Ms strain were procured under a material transfer agreement with the $\mathrm{Na}$ tional Institute of Genetics (Mishima, Japan).

\subsection{Measurement of $\mathrm{O}_{2}$-equilibrium curves}

Hemolysates were prepared according to standard methods and were stripped of organic phosphates and other ionic cofactors by passing the samples through a mixed bed resin column (MB-1 AG501-X8; BioRad, Hercules, CA, USA). The Hb samples were concentrated by ultrafiltration (cutoff 10,000), dialyzed in $\mathrm{CO}$-equilibrated $10 \mathrm{mM}$ HEPES buffer, $\mathrm{pH} 7.6$, and stored at -80 ${ }^{\circ} \mathrm{C}$ as $\mathrm{CO}$-derivatives. The isoHb composition of hemolysates from each mouse strain was confirmed by using thin-layer isoelectric focusing (Phast- System, GE Healthcare Biosciences, Piscataway, NJ, USA). Using a modified diffusion chamber, $\mathrm{O}_{2}$-equilibria of $\mathrm{Hb}$ solutions were measured in $10 \mathrm{mM}$ HEPES buffer, $\mathrm{pH} 7.4$, at constant temperature, $37^{\circ} \mathrm{C}$. The met-Hb enzymatic reducing system of Hayashi et al. (1973) was used to maintain $\mathrm{Hb}$ in the ferrous state. Changes in the absorbance of $\mathrm{Hb}$ solutions were recorded in conjunction with stepwise changes in the partial pressure of $\mathrm{O}_{2}\left[\mathrm{PO}_{2}\right]$ of gas mixtures (prepared using cascaded Wösthoff gas-mixing pumps that perfuse the chamber; Weber, 1981, 1992; Weber et al., 2004).

Values of $\mathrm{P}_{50}$ and $\mathrm{n}_{50}\left(\mathrm{PO}_{2}\right.$ and Hill's cooperativity coefficient, respectively, at $50 \%$ oxygenation of the heme groups) were interpolated from linear Hill plots $\left(\log ([\mathrm{OxyHb}] /[\mathrm{Hb}])\right.$ vs. $\left.\log \mathrm{PO}_{2}\right)$ based on three to five equilibration steps between 20 and $80 \%$ oxygen saturation values.

The $\mathrm{P}_{50}$ values for the stripped (i.e. cofactor-free) hemolysates provide an inverse measure of the intrinsic $\mathrm{O}_{2}$-binding affinities of the major and minor isoHbs occurring in their natural relative concentrations. To assess variation among the different mouse Hbs in the sensitivity to allosteric cofactors, we measured $\mathrm{O}_{2}$-equilibrium curves for each sample in the absence of added cofactors (stripped hemolysates), in the presence of 2,3-diphosphoglycerate (DPG; 2,3- bisphosphoglycerate), in the presence of $\mathrm{Cl}^{-}$ions (added as $\mathrm{KCl}$ ), and in the presence of both cofactors ([Cl-], o.10 M; [NaHEPES], o.1 M; DPG/Hb tetramer ratio, 2.0; [Heme], o.16 mM).

\subsection{Measurement of oxidation rates in the presence of $\mathrm{H}_{2} \mathrm{O}_{2}$}

On the day of the experiment, carboxyHb samples were converted to the oxy form in $\sim 1 \mathrm{~h}$ by photodissociation on ice under air or pure $\mathrm{O}_{2}$. Full conversion to the oxy derivative was checked by UV-visible absorbance spectroscopy. Heme oxidation kinetics of oxyHb were measured at $37{ }^{\circ} \mathrm{C}$ by adding $\mathrm{H}_{2} \mathrm{O}_{2}(20 \mu \mathrm{M}$ final concentration) to a solution of $\mathrm{Hb}(10 \mu \mathrm{M} \text { heme })^{2}$ in o.1 M Hepes, $\mathrm{pH} 7.4$. Absorbance was measured every $10 \mathrm{~s}$ in the range $350-$ $500 \mathrm{~nm}$ using a HP 8453 diode array spectrophotometer. Kinetic traces at $430 \mathrm{~nm}$ were used to calculate initial rates $\left(\mathrm{s}^{-1}\right)$. Statistical differences between rates (values expressed as mean \pm s.e.m., with $n$ as the number of replicates) were assessed by one-way ANOVA, using a significance threshold of $\alpha=0.05$.

\subsection{Analysis of reaction products by SDS-PAGE}

To assess whether the reaction between oxyHb and $\mathrm{H}_{2} \mathrm{O}$ promoted disfulfide polymerization, we incubated $\mathrm{Hb}\left(200 \mu \mathrm{M}^{2}\right.$ heme) in o.1 M Hepes buffer $\mathrm{pH} 7.4$, o.1 M KCl, $100 \mu \mathrm{M}$ DPG (DPG: $\mathrm{Hb}_{4}$ 2:1) with $\mathrm{H}_{2} \mathrm{O}_{2}(400 \mu \mathrm{M})$ at $37^{\circ} \mathrm{C}$ for $1 \mathrm{~h}$ and overnight. Aliquots were then mixed with SDS sample buffer containing 5 $\mathrm{mM}$ NEM to block free thiols, in the presence and absence of 1 $\mathrm{mM}$ DTT, and incubated at $100{ }^{\circ} \mathrm{C}$ for 5 min before loading on a precast PhastSystem (GE Healthcare) 10-15\% SDS-PAGE for analysis of intermolecular disulfide bonds induced by reaction with $\mathrm{H}_{2} \mathrm{O}_{2}$. 


\section{Results}

\subsection{Patterns of $\beta$-globin sequence variation}

In contrast to the $\mathrm{C}_{57} \mathrm{BL} / 6 \mathrm{~J}$ strain, which carries a pair of tandemly duplicated $\beta$-globin genes that are identical in sequence, the $\mathrm{BALB} / \mathrm{cJ}$, MSM/Ms, and CAROLI/EiJ strains each possess structurally distinct $H B B-T_{1}$ and $H B B-T_{2}$ genes (Figure 1 ). On the $H b b^{d}$ haplotype of BALB/cJ, the $H B B-T_{1}$ and $H B B-T_{2}$ genes (which encode the $\beta$-chain subunits of themajor andminor isoHbs $\left[d_{\text {major }}\right.$ and $\left.d_{\text {minor }}\right]$, respectively) are distinguished from one another by nine amino acid substitutions. Similar to the case with the $H b b^{d}$ haplotype, the $H B B-T_{1}$ and $H B B-T_{2}$ genes on the $H b b^{p}$ haplotype of MSM/Ms encode the $\beta$-chain subunits of the major and minor isoHbs $\left(p_{\text {major }}\right.$ and $\left.p_{\text {minor }}\right)$, respectively, and are distinguished from one another by ten amino acid substitutions. The $H b b^{d}$ and $H b b^{p}$ haplotypes share identical $H B B-T_{1}$ sequences $\left(d_{\text {major }}=p_{\text {major }}\right)$, but they are distinguished by two amino acid substitutions at $H B B-T_{2}: \quad \beta_{22}\left(B_{4}\right) G l u \rightarrow$ Ala and $\beta_{23}\left(B_{5}\right)$ Val $\rightarrow$ Ile $\left(d_{\text {minor }} \rightarrow p_{\text {minor }}\right.$, in both cases). Thus, any functional difference between the $\beta$-chain isoHbs produced by the $H b b^{d}$ and $H b b^{p}$ haplotypes would have to be attributable to the two amino acid differences that distinguish the minor isoHbs, $d_{\text {minor }}$ and $p_{\text {minor: }}$ The $H B B-T_{1}$ and $H B B-T_{2}$ genes of CAROLI/EiJ are distinguished from one another by eight amino acid substitutions. Whereas the single $\mathrm{Hb}$ of $\mathrm{C}_{57} \mathrm{BL} / 6 \mathrm{~J}$ contains a single reactive cysteine at $\beta 93$, the major and minor $\beta$-chain isoHbs expressed by the other three strains contain an additional fast-reacting cysteine residue at $\beta_{13}$. The $s$-type $\beta$-globin sequence of $\mathrm{C}_{57} \mathrm{BL} / 6 \mathrm{~J}$ is distinguished from the $H B B-T_{1}$ and $H B B-T_{2}$ sequences of the other three strains by eight to eleven amino acid differences, including the presence of Gly instead of Cys at $\beta_{13}$ (Figure 1, Table 1 ). Aside from the $\beta_{13} \mathrm{Gly} / \mathrm{Cys}$ change, the only other consistent difference between the $s$-type $\mathrm{Hb}$ of $\mathrm{C}_{57} \mathrm{BL} / 6 \mathrm{~J}$ and the major Hbs of the other three strains involves the replacement of Ala for Thr at $\beta_{139}\left(\mathrm{H}_{17}\right)$ (Figure 1$)$.

\section{2. $\mathrm{Hb}-\mathrm{O}_{2}$ affinity}

$\mathrm{O}_{2}$ equilibrium curves revealed that the purified hemolysates of the various mouse strains have fairly similar $\mathrm{O}_{2}$-binding properties. Relative to the Hbs of BALB/cJ, MSM/Ms, and CAROLI/ EiJ, the $s$-type $\mathrm{Hb}$ of $\mathrm{C}_{57} \mathrm{BL} / 6 \mathrm{~J}$ was characterized by a slightly higher $\mathrm{O}_{2}$-affinity (lower $\mathrm{P}_{50}$ ) in the presence and in the absence of DPG and DPG $+\mathrm{Cl}^{-}$ions (Figure 2, Table 2). In each strain, $\mathrm{O}_{2}$ equilibrium measurements revealed that $\mathrm{Cl}^{-}$ions exert a more potent allosteric effect than DPG. Hb-O, affinity was always reduced to a greater extent in the presence of $0.1 \mathrm{~mol} \mathrm{l}^{-1} \mathrm{Cl}^{-}$ions than in the presence of DPG at twofold molar excess over tetrameric Hb. This is indicated by the fact that $\Delta \log \mathrm{P}_{50}$ (KCl-stripped)
Table 1. Amino acid differences between orthologs of $H B B-T_{1}$ and $H B B-$ $T_{2}$ in pairwise comparisons between different stains of house mice. See Figure 1 for information about the nature of the substitutions.

\begin{tabular}{lccc}
\hline & BALB/cJ & MSM/Ms & CAROLI/EiJ \\
\hline$H B B-T 1$ & & & \\
C57BL/6J & 3 & 3 & 12 \\
BALB/cJ & & 0 & 10 \\
MSM/Ms & & & 10 \\
$H B B-T 2$ & & & \\
C57BL/6J & 11 & 13 & 14 \\
BALB/cJ & & 2 & 7 \\
MSM/Ms & & & 9 \\
\hline
\end{tabular}

values were roughly two-fold higher than the corresponding $\Delta \log \mathrm{P}_{50}$ (DPG-stripped) values (Table 2). In each strain, $\mathrm{Hb}-\mathrm{O}_{2}$ affinity was reduced to a similar extent by $\mathrm{KCl}$ alone and by $\mathrm{KCl}^{2} \mathrm{l}$ in combination with DPG $\left(\Delta \log \mathrm{P}_{50}\right.$ [KCl-stripped] values were highly similar to $\Delta \log \mathrm{P}_{50}$ ([DPG+KCl]-stripped) values; Table 2 ). Thus, there does not appear to be any significant competition for binding sites between the monovalent and polyvalent anions.

\subsection{Oxidation rates}

Kinetic measurements revealed that the monocysteinyl $\beta-\mathrm{Hb}$ from the strain $\mathrm{C}_{57} \mathrm{BL} / 6 \mathrm{~J}$ is more readily oxidized to ferric heme by $\mathrm{H}_{2} \mathrm{O}_{2}$ than the dicysteinyl $\beta$-Hbs from the strains BALB/cJ, $\mathrm{MSM}^{2} / \mathrm{Ms}^{2}$, and CAROLI/Eij (Figure 3A,B). These experiments revealed no significant variation in oxidation rates among the dicysteinyl $\beta$-Hbs from BALB/cJ, MSM/Ms, and CAROLI/EiJ.

To assess whether the oxidation of cysteine - $\mathrm{SH}$ groups during incubation with $\mathrm{H}_{2} \mathrm{O}_{2}$ promoted the formation of intermolecular disulphide bonds, we analyzed reaction products by SDSPAGE. The absence of any high-molecular weight band ( 30,0oo; data not shown), indicated that covalent intermolecular polymerization of $\mathrm{Hb}$ polypeptide chains did not occur under the experimental conditions that we used.

\section{Discussion}

Results of our experiments revealed that Hbs from the various mouse strains are similar with respect to $\mathrm{O}_{2}$-binding properties, but $s$-type $\mathrm{Hb}$ from $\mathrm{C}_{57} \mathrm{BL} / 6 \mathrm{~J}$ (which contains a single reactive $\beta$-chain cysteine) was far more readily oxidized to $\mathrm{Fe}^{3+}$ by $\mathrm{H}_{2} \mathrm{O}_{2}$ than the Hbs from BALB/cJ, MSM/Ms, and CAROLI/EiJ (which contain two reactive $\beta$-chain cysteines). These results indicate that the possession of two additional reactive cysteine residues per $\mathrm{Hb}$ tetramer may protect against metHb formation under oxidizing conditions.

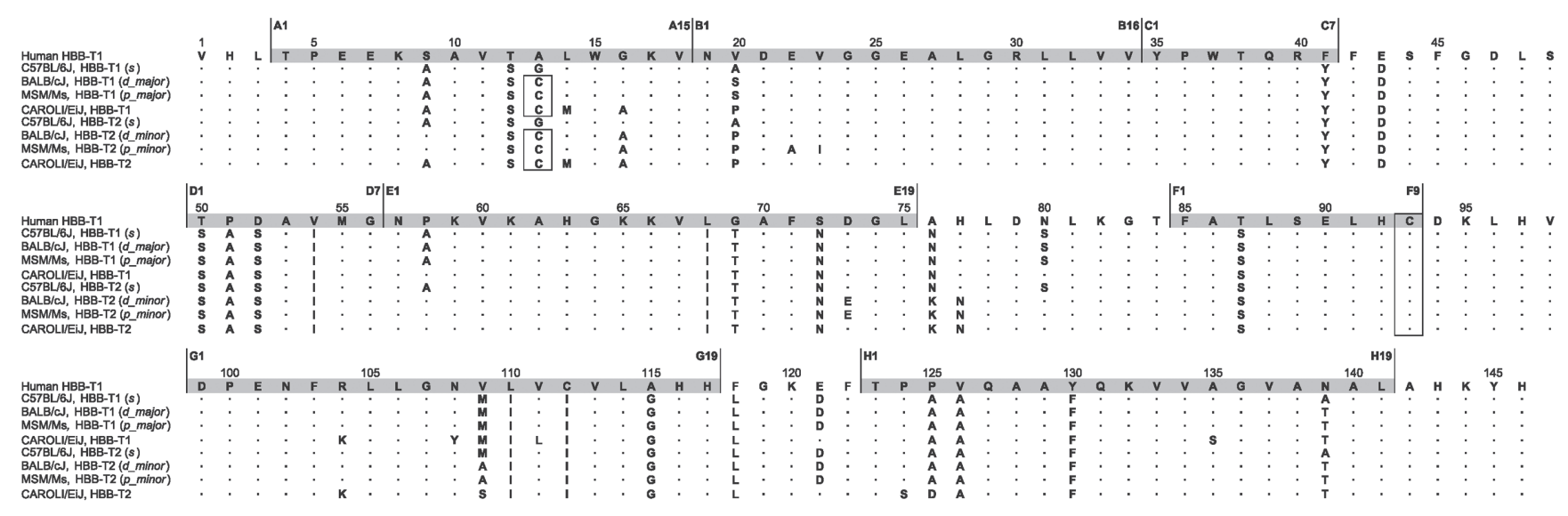

Figure 1. Structural alignment of house mouse $\beta$-globin sequences. Reactive cysteine residues at sites 13 and 93 are shown in boxes. 


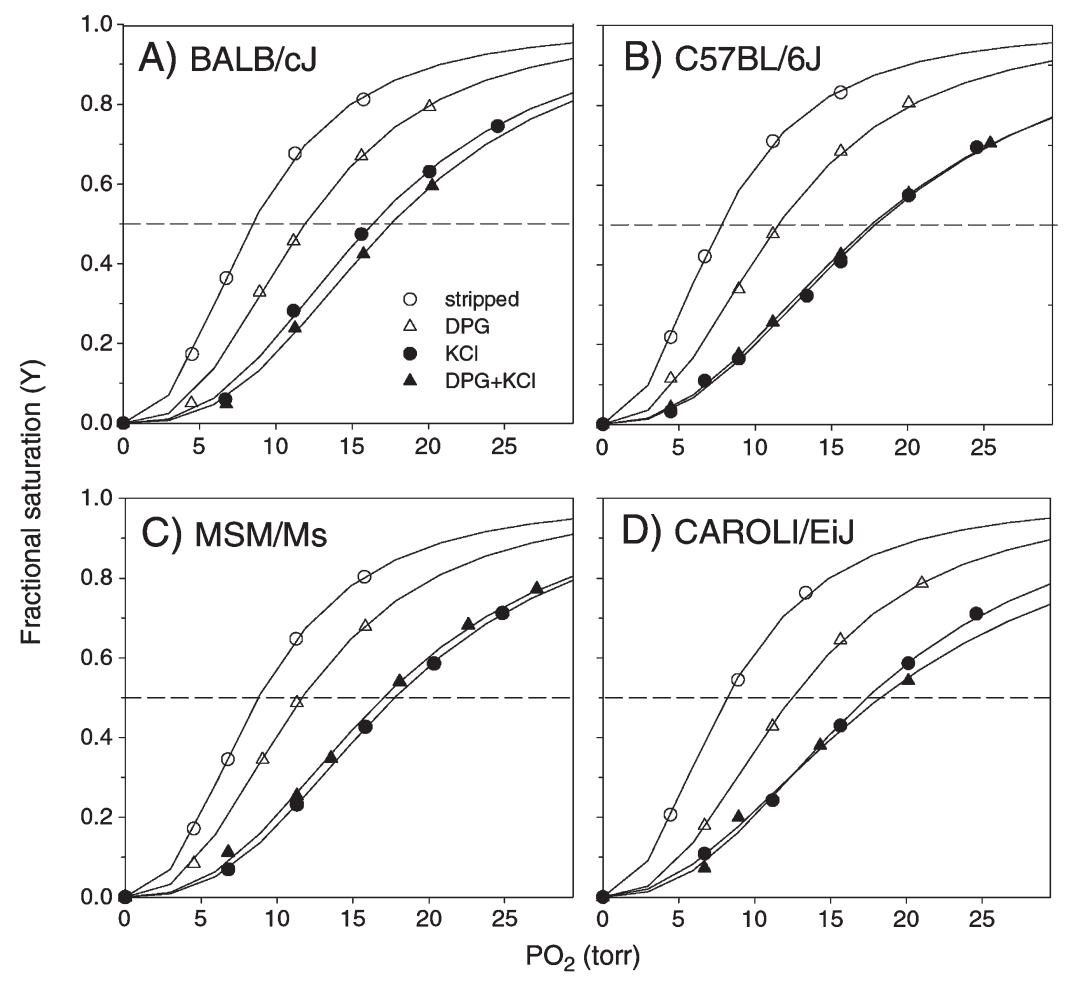

Figure 2. $\mathrm{O}$-equilibrium curves for stripped Hbs from four inbred strains of house mice: (A) BALB/cJ, (B) C57BL/6J, (C) MSM/Ms, and (D) CAROLI/ Eij. $\mathrm{O}_{2}$-equilibria were measured at $37^{\circ} \mathrm{C}$, in o.10 M NaHEPES buffer, at $\mathrm{pH} 7.4 \mathrm{O}$, in the presence and absence of allosteric cofactors [(Cl- $)$, o.1 $\mathrm{M}$; DPG/ $\mathrm{Hb}$ tetramer ratio, 2.o], at $0.16 \mathrm{mM}$ heme concentration, and using the met-Hb reductase system of Hayashi et al. (1973).

\subsection{Variation in $\mathrm{Hb}-\mathrm{O}_{2}$ affinity}

$\mathrm{O}_{2}$-equilibrium measurements of the purified hemolysates revealed that the $s$-type $\mathrm{Hb}$ of $\mathrm{C}_{57} \mathrm{BL} / 6 \mathrm{~J}$ was characterized by a slightly higher $\mathrm{O}_{2}$-affinity than the $d$ - and $p$-type Hbs of BALB/ cJ, MSM/Ms, and CAROLI/Eij (Figure 2, Table 2). Our results are consistent with previous studies of house mouse Hbs (Uchida et al., 1998), which also showed (under different buffer conditions) a relatively weak effect of DPG on $\mathrm{Hb}-\mathrm{O}_{2}$ affinity. Relative to $\mathrm{Hbs}$ of the deer mouse, Peromyscus maniculatus, a similarly sized myomorph rodent, the house mouse Hbs were characterized by similar $\mathrm{O}_{2}$ affinities in the absence of added effectors (stripped) (range of $\mathrm{P}_{50}\left[37^{\circ}, \mathrm{pH} .7 .4\right]$ values $=7.63-8.76$ for house mice and $6.70-8.56$ for deer mice). However, house mouse Hbs are characterized by substantially lower $\mathrm{O}_{2}$ affinities in the presence of DPG and $\mathrm{Cl}^{-}$ions (range of $\mathrm{P}_{50}\left[37^{\circ}, \mathrm{pH}\right.$ 7.4] values $=16.87-18.45$ for house mice and 11.71-15.76 for deer mice; Storz et al., 2009, 2010). One unusual property that is shared between the Hbs of deer mice and house mice is that in both cases $\mathrm{Cl}^{-}$ions exert a stronger allosteric effect than DPG. This is an important finding because DPG is a much more potent allosteric effector than $\mathrm{Cl}^{-}$ions in the overwhelming majority of mammalian Hbs. The only documented exceptions include Hbs from select lineages of artiodactyls, carnivores, moles, and prosimian primates (Bunn, 1971; Taketa et al., 1971; Bunn et al., 1974; Campbell et al., 2010).

\subsection{Variation in oxidation rates}

Results of our experiments revealed far higher rates of $\mathrm{H}_{2} \mathrm{O}_{2}-$ induced heme oxidation in mouse strains with monocysteinyl $\beta$-globins $\left(\mathrm{C}_{57} \mathrm{BL} / 6 \mathrm{~J}\right)$ than in mouse strains with dicysteinyl $\beta$-globins (BALB/cJ, MSM/Ms, and CAROLI/EiJ). This dichotomy in the rate of heme oxidation is mirrored by previously documented variation among mouse strains in red cell survival under oxidative stress: strains like $C_{57} \mathrm{BL} / 6 \mathrm{~J}$ with monocysteinyl $\beta$-globins proved highly resistant to oxidant-induced hemolysis, whereas strains like BALB/cJ with dicysteinyl $\beta$-globins proved far more susceptible to hemolysis (Kruckeberg et al., 1987). Our results, combined with the experimental results of Kruckeberg et al. (1987), suggest that the elevated oxidation rate of the monocysteinyl $\beta$-chain $\mathrm{Hb}$ is associated with increased resistance to hemolysis under conditions of oxidative stress. This is consistent with the hypothesis of Trotta et al. $(1981,1982,1983)$ that, under conditions of oxidative stress, an increased concentration of metHb may confer a protective effect at the cellular level by inhibiting lipid peroxidation.

Table 2. $\mathrm{O}_{2}$ affinity $\left(\mathrm{P}_{50}\right.$, torr; mean \pm s.e.m. $)$ and cooperativity coefficients $\left(n_{50}\right)$ for purified hemolysates measured in o.1 M Hepes buffer at $\mathrm{pH} 7.4 \mathrm{O}, 37^{\circ} \mathrm{C}$, in the presence of the met-Hb reducing system (Hayashi et al., 1973). Measurements were conducted in the absence of DPG and $\mathrm{KCl}$ (stripped), and in the presence of DPG $(\mathrm{DPG} / \mathrm{Hb}$ tetramer ratio = 2.0) or $0.1 \mathrm{M} \mathrm{KCl}$, or both effectors. [Heme], o.16 mM. $N=3$ replicate measurements for $\mathrm{C}_{57} \mathrm{BL} / 6 \mathrm{~J}$, BALB/cJ, and MSM/Ms.

\begin{tabular}{lcllc}
\hline & $C_{57} \mathrm{BL} / 6 \mathrm{~J}$ & $\mathrm{BALB} / \mathrm{cJ}$ & $\mathrm{MSM} / \mathrm{Ms}$ & CAROLI/Ei \\
\hline$P_{50}$ (torr) & & & & \\
Stripped & $7.63 \pm 0.09$ & $8.44 \pm 0.09$ & $8.76 \pm 0.04$ & 8.10 \\
DPG & $10.95 \pm 0.42$ & $11.88 \pm 0.17$ & $11.64 \pm 0.07$ & 12.48 \\
KCl & $17.15 \pm 0.49$ & $16.27 \pm 0.30$ & $17.74 \pm 0.06$ & 17.46 \\
DPG+KCl & $16.87 \pm 0.48$ & $17.53 \pm 0.29$ & $17.03 \pm 0.27$ & 18.45 \\
$\Delta \log P_{50}$ & & & & \\
DPG-stripped & 0.16 & 0.15 & 0.12 & 0.19 \\
KCl -stripped & 0.35 & 0.29 & 0.31 & 0.33 \\
(DPG+KCl) - stripped & 0.34 & 0.31 & 0.29 & 0.36 \\
(DPG+KCl) - KCl & -0.01 & 0.03 & -0.02 & 0.02 \\
(DPG+KCl) - DPG & 0.19 & 0.17 & 0.17 & 0.17 \\
$n_{50}$ & & & & \\
Stripped & $2.24 \pm 0.03$ & $2.46 \pm 0.05$ & $2.40 \pm 0.02$ & 2.28 \\
DPG & $2.44 \pm 0.084$ & $2.65 \pm 0.09$ & $2.50 \pm 0.04$ & 2.53 \\
KCl & $2.36 \pm 0.166$ & $2.68 \pm 0.12$ & $2.67 \pm 0.02$ & 2.57 \\
DPG+KCl & $2.45 \pm 0.011$ & $2.78 \pm 0.13$ & $2.56 \pm 0.09$ & 1.91 \\
\hline
\end{tabular}



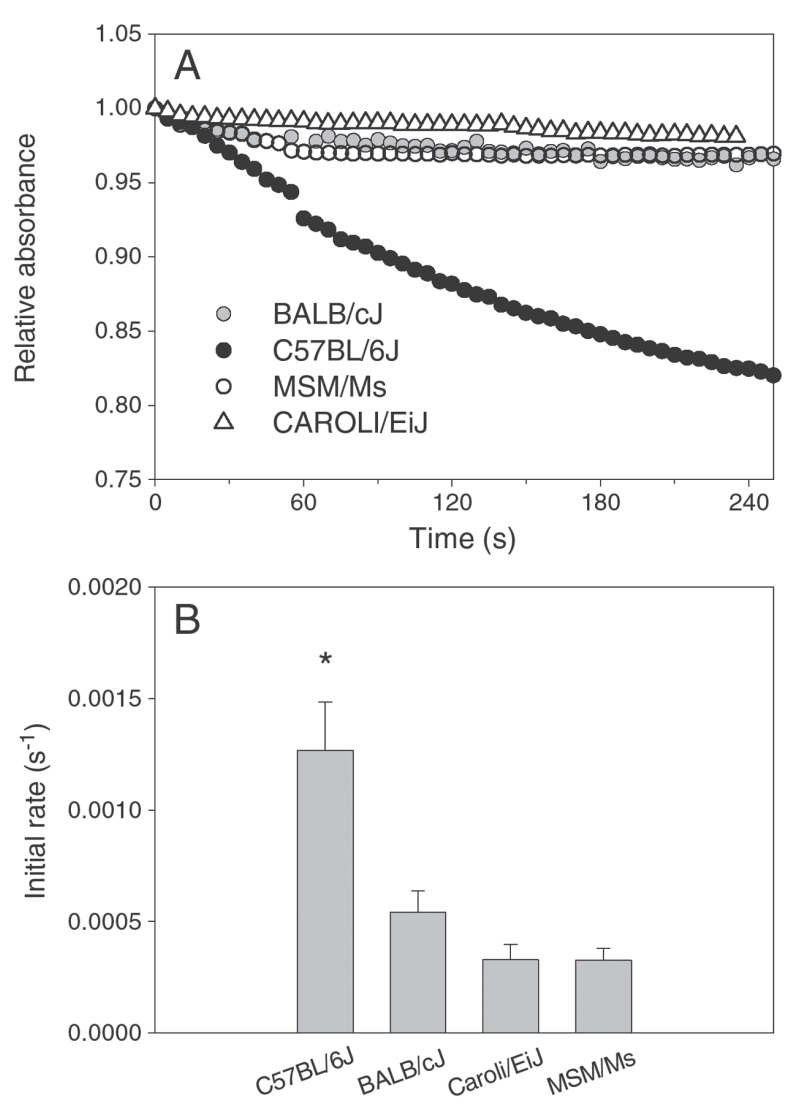

Figure 3. Oxidation of purified Hbs from mouse strains BALB/cJ, $\mathrm{C}_{57} \mathrm{BL} / 6 \mathrm{~J}, \mathrm{MSM} / \mathrm{Ms}$, and CAROLI/EiJ. (A) Representative kinetic traces at $430 \mathrm{~nm}$ and (B) derived initial rates of oxidation $\left(\mathrm{s}^{-1}\right)$ of oxyHb $(10 \mu \mathrm{M}$ heme) to metHb by $\mathrm{H}_{2} \mathrm{O}_{2}$ at a 1:2 molar ratio of heme: $\mathrm{H}_{2} \mathrm{O}_{2}$ at $37{ }^{\circ} \mathrm{C}$ in 0.1 $\mathrm{M}$ Hepes, $\mathrm{pH}$ 7.4. Values are expressed as mean \pm s.e.m. Statistically significant differences $(P<0.05)$ are denoted by an asterisk. Number of replicates (n): BALB/CJ (5), C57BL/6J (4), MSM/Ms (4), and CAROLI/EiJ (5).

\subsection{Structural mechanisms of thiol reactivity and heme oxidation}

In mouse $\mathrm{Hb}$, the especially fast reactivity of $\beta_{13}$ Cys relative to $\beta 93$ Cys appears to be attributable to an increased solvent accessibility and an increased electron density around the sulfur atom of the $\beta_{13}$ Cys thiol group due to the formation of a hydrogen bond with the carbonyl of $\beta 10\left(A_{7}\right)$ Ala (Miranda, 200o). The $\beta_{13} \mathrm{Gly} \rightarrow$ Cys residue change likely confers protection against $\mathrm{H}_{2} \mathrm{O}_{2}$-induced heme oxidation because $\mathrm{H}_{2} \mathrm{O}_{2}$ reacts with the thiol instead of the heme. Since $\mathrm{Hb}$ is primarily oxidized by $\mathrm{H}_{2} \mathrm{O}_{2}$ in the deoxy-ferrous state, the initial oxidation of $\mathrm{Fe}^{2+}$ to $\mathrm{Fe}^{3^{+}}$should be inversely proportional to $\mathrm{O}_{2}$ affinity (Alayash et al., 1999). However, our experiments revealed that the Hb type with the highest oxidation rate was also characterized by the highest $\mathrm{O}_{2}$ affinity (lowest $\mathrm{P}_{50}$ ) at physiological $\mathrm{pH}$ (Table 2), so the observed differences in oxidation rates cannot be explained by differences in $\mathrm{Hb}-\mathrm{O}_{2}$ affinity.

\subsection{Possible adaptive significance of the allelic variation in oxi- dation rates}

Electrophoretic surveys of $\beta$-globin polymorphism in natural populations of Mus musculus and $M$. domesticus have revealed that the $H b b^{d}$ and $H b b^{s}$ haplotypes are consistently present at intermediate frequencies in population samples from across the species' range, a pattern that is not mirrored by other unlinked autosomal genes (reviewed by Storz et al., 2007). This striking uniformity of allele frequencies has led a number of authors to conclude that the two-locus $\beta$-globin polymorphism may be maintained by some form of balancing selection (Berry, 1978). This hypothesis is supported by analyses of nucleotide variation at the $H B B-T_{1}$ and $H B B-T_{2}$ genes, which have revealed remarkably high levels of nucleotide diversity within species (Storz et al., 2007) and the pervasive sharing of $H b b^{d}$ and $H b b^{s}$ haplotypes among multiple Eurasian species in the subgenus Mus (Runck et al., 2009). However, despite the abundance of indirect evidence for the selective maintenance of the $H b b^{d}$ and $H b b^{s}$ haplotypes, there is currently no widely accepted mechanistic explanation for the possible existence of fitness variation among mice with different $\beta$-globin genotypes. One possibility is that the coding mutations in the $H B B$ genes do not directly contribute to fitness variation, but are selectively maintained due to close physical linkage with other (possibly noncoding) sites that represent the true target of balancing selection (Runck et al., 2010). This seems especially plausible since the alternative $s$ - and $d$-type alleles at the two tandemly linked $H B B$ genes are associated with differences in $\mathrm{Hb}$ concentration (Peters et al., 2010). Our results and those of other recent studies (Giustarini et al., 2006; Hempe et al., 2007) suggest that the adaptive significance of the two-locus $\beta$-globin polymorphism could relate specifically to allelic differences in oxidation rate (mediated by $\beta$-globin cysteine content), and may therefore revolve around a signaling function of the $\mathrm{Hb}$ metHb redox couple. Since the intraerythrocytic concentration of reactive sulfydryl groups influences the availability of reduced glutathione for enzymatic detoxification reactions (Di Simplicio et al., 1998; Murakami and Mawatari, 2003; Giustarini et al., 2006; Dalle-Donne et al., 2007; Hempe et al., 2007; Colombo et al., 2010), allelic variation in $\beta$-globin cysteine content may contribute to variation in the cellular response to pathogenic infection and oxidative/nitrosative stress. The differences in met-Hb formation that we documented between strains of mice that express mono- and dicysteinyl $\beta$-chain Hbs suggest that the extensive variation in $\mathrm{Hb}$ cysteine content among different vertebrate taxa (Reischl et al., 2007) may be associated with equally extensive variation in the redox activity of red blood cells.

Acknowledgments - We thank three anonymous reviewers for Comparative Biochemistry and Physiology, Part A for helpful comments and suggestions, and we thank Mai-Britt Hemmingsen for valuable assistance in the lab. This work was funded by grants from the National Institutes of Health/National Heart, Lung, and Blood Institute (Ro1 HLo87216 and HLo87216-S1) and the National Science Foundation (IOS-0949931).

\section{References}

Alayash, A. I., Ryan, B. A. B., Eich, R. F., Olson, J. S., Cashon, R. E., 1999. Reactions of sperm whale myoglobin with hydrogen peroxide - Effects of distal pocket mutations on the formation and stability of the ferryl intermediate. J. Biol. Chem. 274, 2029-2037.

Alayash, A. I., Patel, R. P., Cashon, R. E., 2001. Redox reactions of hemoglobin and myoglobin: Biological and toxicological implications. Antioxid. Redox Signal. 3, 313-327.

Berry, R. J., 1978. Genetic variation in wild house mice: Where natural selection and history meet. Am. Sci. 66, 52-6o.

Bunn, H. F., 1971. Differences in the interaction of 2,3-diphosphoglycerate with certain mammalian haemoglobins. Science 172, 1049-1052.

Bunn, H. F., Seal, U. S., Scott, A. F., 1974. Role of 2,3-diphosphoglycerate in mediating hemoglobin function of mammalian red cells. Ann. N. Y. Acad. Sci. 241, 498-512.

Campbell, K. L., Storz, J. F., Signore, A. V., Moriyama, H., Catania, K. C., Payson, A. P., Bonaventura, J., Stetefeld, J., Weber, R. E., 2010. Molecular basis of a novel adaptation to hypoxic-hypercapnia in a strictly fossorial mole. BMC Evol. Biol. 10, 14.

Colombo, G., Dalle-Donne, I., Giustarini, D., Gagliano, N., Portinaro, N., Colombo, R., Rossi, R., Milzani, A., 2010. Cellular redox potential and hemoglobin S-glutathionylation in human and rat erythrocytes: A comparative study. Blood Cells Mol. Dis. 44, 133-139.

Dalle-Donne, I., Rossi, R., Giustarini, D., Colombo, R., Milzani, A., 2007. S-glutathionylation in protein redox regulation. Free Radic. Biol. Med. $43,883-898$. 
Di Simplicio, P., Cacace, M. G., Lusini, L., Giannerini, F., Giustarini, D., Rossi, R., 1998. Role of protein -SH groups in redox homeostasis The erythrocyte as a model system. Arch. Biochem. Biophys. 355, $145^{-152 .}$

Erhart, M. A., Simons, K. S., Weaver, S., 1985. Evolution of mouse $\beta$-globin genes: A recent gene conversion in the $H b b^{s}$ haplotype. Mol. Biol. Evol. 2, 304-320.

Everse, J., Hsia, N., 1997. The toxicities of native and modified hemoglobins. Free Radic. Biol. Med. 22, 1075-1099.

Giustarini, D., Dalle-Donne, I., Cavarra, E., Fineschi, S., Lungarella, G., Milzani, A., Rossi, R., 2006. Metabolism of oxidants by blood from different mouse strains. Biochem. Pharmacol. 71, 1753-1764.

Gladwin, M. T., Kim-Shapiro, D. B., 2008. The functional nitrite reductase activity of the heme-globins. Blood 112, 2636-2647.

Harel, S., Kanner, J., 1986. Hydrogen peroxide-activated methaemoglobin and other methaemoproteins as initiators of membranal lipid peroxidation. In: Rotilio, G. (Ed.), Superoxide and Superoxide Dismutase in Chemistry, Biology, and Medicine. Elsevier Science, New York, pp. 25-28.

Hayashi, A., Suzuki, T., Shin, M., 1973. An enzymatic reduction system for metmyoglobin and methemoglobin, and its application to functional studies of oxygen carriers. Biochim. Biophys. Acta 310, 309-316.

Hempe, J. M., Ory-Ascani, J., Hsia, D., 2007. Genetic variation in mouse beta globin cysteine content modifies glutathione metabolism: Implications for the use of mouse models. Exp. Biol. Med. 232, 437-444.

Hoffmann, F. G., Opazo, J. C., Storz, J. F., 2008. New genes originated via multiple recombinational pathways in the $\beta$-globin gene family of rodents. Mol. Biol. Evol. 25, 2589-260o.

Jensen, F. B., 2009. The dual roles of red blood cells in tissue oxygen delivery: Oxygen carriers and regulators of local blood flow. J. Exp. Biol. 212, 3387-3393.

Jia, Y. P., Buehler, P. W., Boykins, R. A., Venable, R. M., Alayash, A. I., 2007. Structural basis of peroxide-mediated changes in human hemoglobin - a novel oxidative pathway. J. Biol. Chem. 282, 4894-4907.

Kawashima, T., Miyashita, N., Tsuchiya, K., Li, H., Wang, G., Wang, C. H., Wu, X.-L., Wang, C., Jin, M.-L., He, X.-Q., et al., 1995. Geographical distribution of the Hbb haplotypes in the Mus musculus subspecies in Eastern Asia. Jpn. J. Genet. 70, 17-23.

Kruckeberg, W. C., Doorenbos, D. I., Brown, P. O., 1987. Genetic differences in hemoglobin influence on erythrocyte oxidative stress hemolysis. Blood 70, 909-914.

Leder, P., Hansen, J. N., Konkel, D., Leder, A., Nishioka, Y., Talkington, C., 1980. Mouse globin system: A functional and evolutionary analysis. Science 209, 1336-1342.

Miranda, J. J., 200o. Highly reactive cysteine residues in rodent hemoglobins. Biochem. Biophys. Res. Commun. 275, 517-523.

Miyashita, N., Moriwaki, K., Minezawa, M., Yonekawa, H., Bonhomme, F., Migita, S., Yu, Z., Lu, D., Wang, S. C., Thohari, M., 1985. Allelic constitution of the hemoglobin beta chain in wild populations of the house mouse, Mus musculus. Biochem. Genet. 23, 975-986.

Murakami, K., Mawatari, S., 2003. Oxidation of hemoglobin to methemoglobin in intact erythrocyte by a hydroperoxide induces formation of glutathionyl hemoglobin and binding of $\alpha$-hemoglobin to membrane. Arch. Biochem. Biophys. 417, 244-250.

Newton, M. F., Peters, J., 1983. Physiological variation of mouse haemoglobin. Proc. R. Soc. Lond. B 218, 443-453.

Peters, L. L., Shavit, J. A., Lambert, A. J., Tsaih, S. W., Li, Q. A., Su, Z. G., Leduc, M. S., Paigen, B., Churchill, G. A., Ginsburg, D., et al., 2010. Sequence variation at multiple loci influences red cell hemoglobin concentration. Blood 116, E139-E149.

Reeder, B. J., 2010. The redox activity of hemoglobins: From physiologic functions to pathologic mechanisms. Antioxid. Redox Signal. 13, 1087-1123.

Reischl, E., Dafre, A. L., Franco, J. L., Wilhelm, D., 2007. Distribution, adaptation and physiological meaning of thiols from vertebrate hemoglobins. Comp. Biochem. Physiol. C 146, 22-53.
Riggs, A., 1960. The nature and significance of the Bohr effect in mammalian hemoglobins. J. Gen. Physiol. 43, 737-752.

Runck, A. M., Moriyama, H., Storz, J. F., 2009. Evolution of duplicated $\beta$-globin genes and the structural basis of hemoglobin isoform differentiation in Mus. Mol. Biol. Evol. 26, 2521-2532.

Runck, A. M., Weber, R. E., Fago, A., Storz, J. F., 2010. Evolutionary and functional properties of a two-locus $\beta$-globin polymorphism in Indian house mice. Genetics 184, 1121-1131.

Selander, R. K., Yang, S. Y., 1969. Protein polymorphism and genic heterozygosity in a wild population of the house mouse (Mus musculus). Genetics 63, 653-667.

Selander, R., Yang, S., Hunt,W., 1969a. Polymorphisms in esterases and hemoglobin in wild populations of the house mouse (Mus musculus). Univ. Texas Publ. 6918, 271-338.

Selander, R. K., Hunt, W. G., Yang, S. Y., 1969b. Protein polymorphism and genic heterozygosity in two European subspecies of the house mouse. Evolution 379-390.

Storz, J. F., Baze, M., Waite, J. L., Hoffmann, F. G., Opazo, J. C., Hayes, J. P., 2007. Complex signatures of selection and gene conversion in the duplicated globin genes of house mice. Genetics 177, 481-500.

Storz, J. F., Runck, A. M., Sabatino, S. J., Kelly, J. K., Ferrand, N., Moriyama, H., Weber, R. E., Fago, A., 2009. Evolutionary and functional insights into the mechanism underlying high-altitude adaptation of deer mouse hemoglobin. Proc. Natl. Acad. Sci. U.S.A. 106, 14450-14455.

Storz, J. F., Runck, A. M., Moriyama, H., Weber, R. E., Fago, A., 2010. Genetic differences in hemoglobin function between highland and lowland deer mice. J. Exp. Biol. 213, 2565-2574.

Taketa, F., Mauk, A. G., Lessard, J. L., 1971. $\beta$ chain amino termini of the cat hemoglobins and the response to 2,3-diphosphoglycerate and adenosine triphosphate. J. Biol. Chem. 246, 4471-4476.

Thomas, J. A., Mallis, R. J., Sies, H., 2003. Protein S-thiolation, S-nitrosylation, and irreversible sulfydryl oxidation: Roles in redox regulation. In: Gitler, C., Danon, A. (Eds.), Cellular Implications of Redox Signaling. Imperial College Press, London, pp. 141-174.

Trotta, R. J., Sullivan, S. G., Stern, A., 1981. Lipid peroxidation and hemoglobin degradation in red blood cells exposed to t-butyl hydroperoxide: Dependence on glucose metabolism and hemoglobin status. Biochim. Biophys. Acta 679, 230-237.

Trotta, R. J., Sullivan, S. G., Stern, A., 1982. Lipid peroxidation and haemoglobin degradation in red blood cells exposed to t-butyl hydroperoxide: Effects of the hexose monophosphate shunt as mediated by glutathione and ascorbate. Biochem. J. 204, 405-415.

Trotta, R. J., Sullivan, S. G., Stern, A., 1983. Lipid peroxidation and haemoglobin degradation in red blood cells exposed to t-butyl hydroperoxide: the relative roles of haem- and glutathione-dependent decomposition of t-butyl hydroperoxide and membrane lipid hydroperoxides in lipid peroxidation and haemolysis. Biochem. J. 212, 759-772.

Uchida, K., Reilly, M. P., Asakura, T., 1998. Molecular stability and function of mouse hemoglobins. Zool. Sci. 15, 703-706.

Umbreit, J., 2007. Methemoglobin - it's not just blue: A concise review. Am. J. Hematol. 82, 134-144.

Weber, R. E., 1981. Cationic control of oxygen affinity in lugworm erythocruorin. Nature 292, 386-387.

Weber, R. E., 1992. Use of ionic and zwitterionic (Tris/BisTris and HEPES) buffers in studies on hemoglobin function. J. Appl. Physiol. 72, $1611-1615$.

Weber, R. E., Voelter, W., Fago, A., Echner, H., Campanella, E., Low, P. S., 2004. Modulation of red cell glycolysis: interactions between vertebrate hemoglobins and cytoplasmic domains of band 3 red cell membrane proteins. Am. J. Physiol. Regul. Integr. Comp. Physiol. 287, R454-R464.

Whitney, J. B., 1977. Differential control of the synthesis of two hemoglobin beta chains in normal mice. Cell 12, 863-871.

Widmer, C. C., Pereira, C. P., Gehrig, P., Vallelian, F., Schoedon, G., Buehler, P. W., Schaer, D. J., 2010. Hemoglobin can attenuate hydrogen peroxide-induced oxidative stress by acting as an antioxidative peroxidase. Antioxid. Redox Signal. 12, 185-198. 